\title{
Extraction, Toxicity Assay and Identification of Active Compounds of Red Algae (Eucheuma cottonii) from Sumenep Madura
}

\author{
Sholeh Afif, A. Ghanaim Fasya, Rachmawati Ningsih \\ Jurusan Kimia Fakultas Sains dan Teknologi Universitas Islam Negeri Maulana Malik Ibrahim Malang \\ Email: shol89fif@gmail.com
}

\begin{abstract}
Extraction, Toxicity Assay and Identification ofActive Compounds of Red Algae Extract (Eucheuma cottonii) from Tanjung Sumenep Madura was analysed. Extraction of active compound was conducted by maceration method using methanol as a solvent. The methanol extract was hydrolyzed with $\mathrm{HCl} 2 \mathrm{~N}$. The result was partitioned using five solvents (1-butanol, ethyl acetate, chloroform, petroleum ether and n-hexane). Toxicity level was determined by Brine Shrimp Lethality Test (BSLT). The identification of the active compound was analyzed by phytochemical test, qualitatively. The result showed that the 1-butanol is the best solvent to extract active compounds of red algae E. Cottonii in partition process. 1-Butanol fraction gives the highest activity of toxicity with $\mathrm{LC}_{50} 70,32 \mathrm{ppm}$. $\mathrm{LC}_{50}$ value for ethyl acetate, chloroform, petroleum ether and nhexane was 143,$43 ; 194,40 ; 195,28 ; 303,66$; and 634,97 ppm, respectively. Identification of active compounds indicated that 1-butanol fraction contains steroids and alkaloids.
\end{abstract}

Keywords: Eucheuma cottonii, extraction, Brine Shrimp Lethality Test, phythochemical

\begin{abstract}
Abstrak
Ekstraksi, uji toksisitas dan identifikasi golongan senyawa aktif ekstrak alga merah Eucheuma cottonii dari Pantai Tanjung Sumenep Madura telah dianalisis. Ekstraksi senyawa aktif dilakukan dengan metode maserasi menggunakan pelarut metanol. Ekstrak pekat metanol dihidrolisis dengan $\mathrm{HCl} 2 \mathrm{~N}$. Hidrolisat dipartisi menggunakan lima jenis pelarut yaitu 1-butanol, etil asetat, kloroform, petroleum eter dan $n$-heksana. Uji toksisitas menggunakan Brine Shrimp Lethality Test. Identifikasi golongan senyawa aktif dilakukan secara kualitatif dengan uji fitokimia. Hasil penelitian menunjukkan bahwa 1-butanol merupakan pelarut yang terbaik untuk mengekstrak senyawa aktif alga merah E. cottonii dengan metode partisi. Pelarut ini memberikan toksisitas tertinggi dengan nilai $\mathrm{LC}_{50}$ sebesar $70,32 \mathrm{ppm}$. Nilai $\mathrm{LC}_{50}$ pada pelarut etil asetat; metanol; petroleum eter; kloroform dan n-heksana masing-masing sebesar 143,43; 194,40; 195,28; 303,66; dan 634,97 ppm. Hasil identifikasi golongan senyawa aktif $E$. cottonii menunjukkan bahwa fraksi 1-butanol mengandung steroid dan alkaloid.
\end{abstract}

Kata Kunci: Eucheuma cottonii, ekstraksi, Brine Shrimp Lethality Test, fitokimia

\section{Pendahuluan}

Dua pertiga luas wilayah Indonesia merupakan lautan yang mempunyai potensi sumber daya alam yang sangat penting bagi kehidupan bangsa. Salah satu sumber daya alam yang cukup potensial dari perairan laut Indonesia adalah rumput laut dengan berbagai macam jenisnya. Rumput laut dapat dijumpai di hampir seluruh perairan Indonesia. Budidaya rumput laut telah dilakukan di beberapa daerah, antara lain di Pulau Lombok, Nusa Tenggara Barat (NTB) dan di Pulau-pulau Jawa serta Madura. Rumput laut merupakan bagian dari tanaman perairan, yang termasuk pada kelas makroalga (Costa, 2003).

Para ahli menggolongkan rumput laut menjadi 5 kelompok yaitu Cyanophyta (alga biru), Chlorophyta (alga hijau), Chrysophyta (alga keemasan), Phaeophyta (alga coklat), dan Rhodophyta (alga merah). Tetapi, potensi yang banyak dimanfaatkan adalah jenis Rhodophyta (alga merah) dengan berbagai jenis diantaranya Eucheuma cottonii, Eucheuma spinosum, Eucheuma edule (Junaedi, 2004). Alga merah E. cottonii banyak 
ditemukan di daerah pantai Jumiang Pamekasan, pantai Tanjung Sumenep dan daerah-daerah lain di perairan Madura. Hasil produksi rumput laut di daerah tersebut mencapai puluhan ton per tahun. Sebagian rumput laut tersebut diekspor dan sebagian besar dijadikan bahan makanan.

Tujuan dari penelitian ini adalah untuk mengetahui pelarut yang terbaik dalam mengekstrak senyawa aktif alga merah E. cottonii dari Pantai Tanjung Sumenep Madura. Selain itu, ditentukan pula nilai toksisitas dan kandungan metabolit sekunder pada ekstrak alga merah.

\section{Metode Penelitian \\ 2.1 Bahan}

Bahan yang digunakan dalam penelitian ini adalah alga merah jenis $E$. cottonii yang diperoleh dari pantai Tanjung, Sumenep, Madura.

\subsection{Uji Taksonomi}

Uji taksonomi dilakukan untuk mengidentifikasi klasifikasi alga merah $E$. cottonii dilakukan di Laboratorium Bioteknologi Jurusan Biologi Universitas Islam Negeri Maulana Malik Ibrahim Malang.

\subsection{Preparasi Sampel}

Alga merah E. cottonii segar dicuci dan kemudian dikeringkan pada suhu $38^{\circ} \mathrm{C}$ selama 24 jam. Alga kering dihaluskan dan diayak dengan ukuran 80-100 mesh.

\subsection{Analisis Kadar Air}

Analisis kadar air dilakukan pada $E$. cottonii. Cawan dipanaskan dalam oven pada suhu $100-105^{\circ} \mathrm{C}$ selama 15 menit kemudian disimpan dalam desikator vakum selama 10 menit. Cawan tersebut ditimbang dan dilakukan perlakuan yang sama sampai berat cawan konstan.

Sampel basah sebanyak 5 gram dimasukkan dalam cawan dan dikeringkan dalam oven pada suhu $100-105^{\circ} \mathrm{C}$ selama
15 menit. Setelah itu, sampel disimpan dalam desikator vakum selama 10 menit dan ditimbang. Perlakuan ini diulangi hingga diperoleh berat konstan.

\subsection{Analisis Kadar Garam}

Lima gram sampel dimasukkan dalam gelas kimia, ditambahkan $10 \mathrm{~mL}$ akuades, dan diaduk selama 15 menit. Proses tersebut diulangi sebanyak 10 kali agar garam pada sampel larut dalam akuades. Setelah itu, sampel disaring menggunakan penyaring vacum buchner. Garam yang sudah terekstrak ke dalam pelarut akuades diukur kadarnya menggunakan salinometer. Garam dalam larutan tersebut diukur sebagai konsentrasi kepekatan.

\subsection{Ekstraksi Sampel}

Alga merah E. cottonii halus sebanyak 100 gram direndam dalam 300 mL metanol (Hukmah, 2007). Selanjutnya, diaduk menggunakan shaker dengan kecepatan 120 rpm selama 24 jam. Larutan ekstrak alga merah disaring dan ampas yang diperoleh dimaserasi kembali sebanyak dua kali dengan pelarut dan perlakuan yang sama. Ekstrak alga merah dipekatkan dengan rotary evaporator vacum dan diperoleh ekstrak pekat.

Ekstrak pekat hasil maserasi dihidrolisis dengan $5 \mathrm{~mL} \mathrm{HCl} 2 \mathrm{~N}$ selama 1 jam pada suhu $40{ }^{\circ} \mathrm{C}$ dan didinginkan (Tensiska, dkk., 2007). Hidrolisat yang diperoleh ditambah natrium bikarbonat hingga $\mathrm{pH}$ netral, dan dipartisi menggunakan pelarut 1-butanol, etil asetat, kloroform, petroleum eter dan n-heksana dengan perbandingan 1:1. Pada pelarut non polar ditambahkan DMSO untuk membantu proses pelarutan.

\subsection{Uji Toksisitas Ekstrak Alga Merah Mengunakan BSLT \\ 2.7.1 Penetasan Larva Udang}

Penetasan larva didasarkan pada metode dari Swantara (2000). Telur 
Artemia salina Leach sebanyak $2,5 \mathrm{mg}$ dimasukkan dalam botol penetasan yang berisi $250 \mathrm{~mL}$ air laut. Selama proses penetasan dilakukan aerasi. Telur akan menetas setelah \pm 48 jam dan siap digunakan sebagai target uji toksisitas.

\subsubsection{Uji Toksisitas (Rita, dkk., 2008)}

Kelima fraksi sebanyak $100 \mathrm{mg}$ dilarutkan dalam $10 \mathrm{~mL}$ pelarutnya masing-masing. Larutan tersebut dipipet masing-masing $200 \mu \mathrm{L}, 150 \mu \mathrm{L}, 100 \mu \mathrm{L}$, $50 \mu \mathrm{L}$ dan $25 \mu \mathrm{L}$ dan dimasukkan ke dalam botol vial. Setelah itu, pelarutnya diuapkan hingga kering. Seratus mililiter DMSO, satu tetes larutan ragi roti dan 2 $\mathrm{mL}$ air laut ditambahkan pada botol vial kemudian campuran tersebut dikocok hingga homogen. Larutan campuran dipindahkan dalam labu ukur $10 \mathrm{~mL}$, dimasukkan 10 ekor larva udang Artemia salina dan ditambahkan air laut sampai volumenya menjadi $10 \mathrm{~mL}$. Konsentrasi masing-masing larutan adalah 200, 150, 100, 50 dan 25 ppm.

Larutan kontrol dibuat sama dengan prosedur diatas namun tidak menambahkan sampel. Pengamatan dilakukan selama 24 jam terhadap kematian larva udang. Analisis data dilakukan untuk mencari nilai $\mathrm{LC}_{50}$ dengan analisis probit menggunakan program MINITAB 16 dengan tingkat kepercayaan $95 \%$ dan margin error $5 \%$.

\subsection{Uji Fitokimia Ekstrak Alga Merah}

Uji kandungan senyawa aktif dilakukan pada ekstrak dengan nilai toksisitas tertinggi. Uji fitokimia yang dilakukan meliputi alkaloid, flavonoid, dan triterpenoid/steroid (Indrayani, dkk., 2006).

\subsubsection{Uji Alkaloid}

Ekstrak alga merah E. cottonii dimasukkan dalam tabung reaksi, ditambah $0,5 \mathrm{~mL} \mathrm{HCl} 2 \%$ dan larutan dibagi dalam dua tabung. Tabung I ditambahkan $0.5 \mathrm{~mL}$ reagen Dragendorff, tabung II ditambahkan 2-3 tetes reagen Mayer. Jika tabung I terbentuk endapan jingga dan pada tabung
II terbentuk endapan kekuning-kuningan, menunjukkan adanya alkaloid.

\subsubsection{Uji Flavonoid}

Ekstrak alga merah E. cottonii dilarutkan dalam 1-2 mL metanol panas 50 $\%$. Setelah itu, ditambah logam Mg dan 0,5 $\mathrm{mL} \mathrm{HCl}$ pekat. Warna merah atau jingga yang terbentuk pada sampel menunjukkan adanya flavonoid.

\subsubsection{Uji Triterpenoi/ Steroid}

Ekstrak alga merah E. cottonii dilarutkan dalam $0,5 \mathrm{~mL}$ kloroform dan direaksikan dengan $0,5 \mathrm{~mL}$ asam asetat anhidrat. Campuran tersebut ditambah 1-2 $\mathrm{mL} \mathrm{H}_{2} \mathrm{SO}_{4}$ pekat melalui dinding tabung. Hasil positif terpenoid ditunjukkan dengan terbentuknya cincin kecoklatan atau violet pada perbatasan dua pelarut, sedangkan hasil positif steroid ditunjukkan dengan terbentuknya warna hijau kebiruan.

\subsection{Analisis Data}

Data yang diperoleh dibuat dalam bentuk tabel dan grafik Analisis probit pada uji toksisitas dilakukan menggunakan program MINITAB 16 dengan tingkat kepercayaan $95 \%$ an margin error $5 \%$.

\section{Hasil dan Pembahasan}

\subsection{Uji Taksonomi}

Uji taksonomi menunjukkan bahwa alga merah tersebut memiliki ciri-ciri; talus silindris, permukaan licin, cartilogeneus, warna merah, bentuk talus kompleks, duri pada talus runcing memanjang banyak dan tidak bersusun melingkari talus, percabangan ke berbagai arah dengan batang utama keluar saling berdekatan ke daerah basal (pangkal). Berdasarkan ciriciri tersebut dapat disimpulkan bahwa sampel mirip dengan jenis Eucheuma cottoniii Weber-van Bosse atau sinonim: Kappaphycus alvarezzi (doty) Doty ex P.C. Silva. 


\subsection{Preparasi Sampel}

Preparasi sampel diawali dengan pengeringan dan penghalusan yang bertujuan untuk menghasilkan ekstraksi yang maksimal. Menurut Suryaningrum (2006). ekstrak kasar maupun hasil fraksinasi sampel kering pada E. cottoniii memiliki toksisitas yang lebih baik dibandingkan dengan sampel segar. Proses penghalusan sampel dilakukan agar luas permukaan semakin besar sehingga interaksi metabolit sekunder dan pelarut semakin optimal. Selain itu, penghalusan juga mempermudah sel-sel alga merah terpecah sehingga senyawa aktif mudah terekstrak. Serbuk alga merah disimpan dalam wadah kedap udara untuk mengurangi degradasi mikroorganisme.

\subsection{Analisis Kadar Air}

Hasil pengukuran ini menunjukkan bahwa sampel yang dianalisis mempunyai kadar air cukup baik untuk dilakukan proses ekstraksi (Tabel 1). Semakin rendah kadar air suatu sampel maka semakin mudah pelarut untuk mengekstrak komponen senyawa aktif. Sulistijowati (2001) menyatakan bahwa kadar air maksimum yang disyaratkan agar proses ekstraksi dapat berjalan lancar yaitu sebesar $11 \%$.

Tabel 1. Kadar air ekstrak E. cottonni

\begin{tabular}{lc}
\hline \multicolumn{1}{c}{ Ekstrak } & Kadar Air $(\% \mathrm{~b} / \mathrm{b})$ \\
\hline Sampel basah & 79,6 \\
Sampel kering & 4,74 \\
\hline
\end{tabular}

\subsection{Analisis Kadar Garam}

Hasil analisis kadar garam menunjukkan bahwa sampel basah mempunyai jumlah kadar garam lebih kecil dibandingkan sampel kering (Tabel 2). Kadar garam yang tinggi pada sampel kering tidak menunjukkan efek yang signifikan terhadap sifat toksisitas sampel.

Hasil ini didukung oleh Matthew (1982) yang menyatakan bahwa paparan salinitas antara 22,7 dan 33,0 ppt tidak memberikan pengaruh yang signifikan terhadap perkembangan embrio normal mikrolga.

\subsection{Ekstraksi Sampel}

Ekstraksi yang digunakan pada penelitian ini adalah maserasi dan partisi (cair-cair). Ekstrak hasil maserasi dilakukan proses hidrolisis menggunakan asam kuat, $\mathrm{HCl}$. Proses ini bertujuan untuk memisahkan antara senyawa glikon dan aglikon pada senyawa glikosida. Hidrolisat dilakukan ekstraksi kembali dengan partisi dengan lima variasi pelarut yaitu nheksana, klororform, petroleum eter, 1butanol, dan etil asetat. Pelarut-pelarut tersebut memiliki kepolaran yang berbeda sehingga diharapkan mampu mengekstrak senyawa yang memiliki kepolaran berbeda pula. Rendemen hasil ekstraksi maserasi sebesar 16,97 \%, sedangkan hasil rendemen partisi pada 1-butanol, etil asetat, kloroform, petroleum eter dan nheksana masing-masing sebesar 4,94\%; $8,54 \% ; 16,98 \% ; 10,7 \%$ dan $5,14 \%$.

Tabel 2. Kadar garam ekstrak E. cottonnii

\begin{tabular}{lc}
\hline \multicolumn{1}{c}{ Ekstrak } & Kadar Garam $(\% \mathrm{~b} / \mathrm{b})$ \\
\hline Sampel basah & 4,50 \\
Sampel kering & 25,5 \\
\hline
\end{tabular}

\subsection{Uji Toksisitas Menggunakan BSLT (Brine Shrimp Lethality Test)}

Data nilai $\mathrm{LC}_{50}$ pada Tabel 3 menunjukkan bahwa ekstrak alga merah mampu membunuh 50\% hewan uji. Semua ekstrak tersebut memiliki sifat toksik. Penentuan ini didasarkan pada Wahyuni (2003) yang menyatakan bahwa suatu ekstrak bersifat toksik apabila memiliki nilai $\mathrm{LC}_{50}$ kurang dari $1000 \mathrm{ppm}$. Nilai $\mathrm{LC}_{50}$ didefinisikan sebagai konsentrasi zat yang menyebabkan terjadinya kematian pada 50\% larva Artemia salina Leach sebagai hewan uji.

Lisdawati (2002) menyebutkan bahwa semakin kecil nilai $\mathrm{LC}_{50}$ maka semakin besar aktivitas biologi/efek 
farmakologi ekstrak tersebut, salah satunya sebagai antitumor. Winarno (2002) menyatakan bahwa nilai $\mathrm{LC}_{50}$ antara 30 200 ppm berpotensi sebagai antimikroba. Berdasarkan Tabel 3, ekstrak yang paling berpotensi sebagai antitumor dan antimikroba adalah fraksi 1-butanol dengan nilai $\mathrm{LC}_{50}$ sebesar 70,32 ppm.

Tabel 3. Nilai $\mathrm{LC}_{50}$ pada Berbagai Pelarut

\begin{tabular}{lc}
\hline \multicolumn{1}{c}{ Fraksi } & Nilai $\mathrm{LC}_{50}(\mathrm{ppm})$ \\
\hline Metanol & 194,4 \\
1-Butanol & 70,32 \\
Etil asetat & 143,4 \\
Kloroform & 303,7 \\
Petroleum eter & 195,3 \\
n-heksana & 635,0 \\
\hline
\end{tabular}

\subsection{Uji Fitokimia Ekstrak Alga Merah}

Ekstrak methanol alga merah mengandung metabolit sekunder yang meliputi flavonoid, steroid dan alkaloid. Metabolit sekunder ekstrak etil asetat adalah alkaloid, triterpenoid dan steroid, sedangkan ekstrak kloroform adalah flavonoid, triterpenoid dan alkaloid.. Menurut Widyawati (2011), metanol secara efektif dapat mengekstrak senyawa polar, seperti flavonoid, fenolik dan saponin. Sedangkan etil asetat dilaporkan dapat mengekstrak senyawa saponin, alkaloid, triterpenoid, steroid dan flavonoid. Hasil uji fitokimia menunjukkan bahwa fraksi 1-butanol mengandung senyawa aktif berupa steroid dan alkaloid.

Steroid dan alkaloid merupakan senyawa yang berpotensi sebagai antimikroba karena dapat merusak dinding sel. Farouk, dkk. (2007) menyatakan bahwa metabolit sekunder yang berpotensi sebagai senyawa antimikroba adalah golongan atau turunan dari senyawa terpenoid, diantaranya steroid, triterpenoid dan alkaloid. Golongan senyawa tersebut memiliki polisakarida sehingga dapat menembus membran sel bakteri, sehingga sel tersebut rusak. Lamothe (2009) menyatakan mekanisme kerja alkaloid sebagai antimikroba diprediksi melalui penghambatan sintesis dinding sel yang akan menyebabkan lisis pada sel sehingga akan rusak dan mati.

\section{Kesimpulan}

Pelarut terbaik untuk mengekstrak E. cottonii adalah 1-butanol dengan metode partisi. Fraksi 1-butanol memiliki nilai toksisitas tertinggi dengan nilai $\mathrm{LC}_{50} 70,32$ ppm. Fraksi ini mengandung metabolit sekunder yang terdiri atas steroid dan alkaloid.

\section{Daftar Pustaka}

Doty MS. 1985. Eucheuma alvarezii sp.nov (Gigartinales, Rhodophyta) from Malaysia. Di dalam: Abbot IA, Norris JN (editors). Taxonomy of Economic Seaweeds. California Sea Grant College Program.

Farouk, A.E., Faizal A.H.G., dan Ridzwan B.H.. 2007. New Bacterial Species Isolated from Malaysian Sea Cucumbers with Optimized Secreted Antibacterial Activity. American Journal of Biochemistry and Biotechnology: 64-69.

Hukmah, S. 2007. Aktivitas Antioksidan Katekin dari Teh Hijau (Camellia Sinensis O.K. Var. Assamica (mast)) Hasil Ekstraksi dengan Variasi Pelarut dan Suhu. Skripsi. Universitas Islam Negeri Maulana Malik Ibrahim Malang, Malang.

Indrayani, L., H. Soetjipto, dan L. Sihasale. 2006. Skrinning Fitokimia dan Uji Toksisitas Ekstrak Daun Pecut Kuda (Stachytarpheta jamaicensis L. Vahl) Terhadap Larva Udang Artemia salina Leach. Jurnal Fakultas Sains dan Matematika, Universitas Kristen Satya Wacana Salatiga.

Junaedi, W. 2004. Rumput Laut, Jenis dan Morfologi. Direktorat Jenderal Pendidikan Dasar Dan Menengah Kejuruan, Jakarta. 
Lamothe, R.G. 2009. Plant Antimicrobial Agents and Their Effects on Plant and Human Pathogens. International Journal of Molecular Science, 10: 3400-3419.

Lisdawati, V. 2002. Berdasar Uji Penapisan Farmakologi pada Buah Mahkota Dewa. Fakultas Kedokteran. Yogyakarta: Universitas Gajamada.http://www.farmakologi.fk. ugm.ac.id/2008/05/30/berdasarujipenapsisanfarmakologi-padabuah-mahkota-dewa/.

Diakses tanggal 15 Januari 2009.

Matthew P.C. 1982. The Effects of Salinity on Copper and Silver Toxicity to Embryos of the Pacific Oyster. California Department of Fish and Game, Marine Bioassay Laboratory, California.

Rita, W. S., Suirta, I.W. dan Sabirin, A. 2008. Isolasi dan Identifikas iSenyawa yang Berpotensi Sebagai Antitumor pada Daging Buah Pare (Momordica carantia L). Jurnal Kimia, Vol. 2(1): 1-6.

Sulistijowati, S. dan Gunawan, D. 2001. Efek Ekstrak Daun Kembang Bulan (Tithonia difersifolia A. Gray) Terhadap Candica albicans Serta Profil Kromatografinya. Pusat Penelitian dan Pengembangan Kesehatan, Jakarta.

Suryaningrum, D. dkk.,2006. Uji Aktivitas Senyawa Antioksidan dari Rumput Laut Halymenia harveyana dan Eucheuma cottonii. Universitas Diponegoro, Semarang.

Swantara, I.M. 2001. Identifikasi Senyawa Aktif Antibakteri dalam Tumbuhan Kentut-kentut (Paederia foetida Auct.). Fakultas Matematika dan Ilmu Pengetahuan Alam, Universitas Udayana, Denpasar.

Tensiska, I.S, Setiasih, dan Irawati, D. 2007. Deskripsi Minuman Emulsi VCO pada Berbagai Jumlah
Penambahan Air. Prosiding Seminar Nasional Patpi, Bandung. 17-18.

Wahyuni, S. I. 2003. Uji Fitokimia Tanaman Anting-Anting (Acalypha indica L.) dengan Variasi Pelarut dan Uji Toksisitas Menggunakan Brine Shrimp (Artemia salina Leach). Skripsi Tidak Diterbitkan. Jurusan Kimia Universitas Islam Negeri Maulana Malik Ibrahim Malang, Malang.

Widyawati, P.S. 2011. Aktivitas Antioksidan Ekstrak Metanolik Daun Beluntas (Pluchea indica Less) dan Fraksinya serta Kemampuan Mencegah Warmed Over Flavor pada Daging Itik yang telah Dipanaskan. Tesis. Program Pasca Sarjana, Institut Pertanian Bogor, Bogor.

Winarno, F. G. 2002. Kimia Pangan dan Gizi. Jakarta: PT Gramedia Pustaka Utama. 